\title{
Przedsiębiorczość MŚP sektora high-tech z Wielkopolski
}

\author{
Matgorzata Gajowiak*
}

\begin{abstract}
Artykut podejmuje kwestie dotyczace przedsiębiorczości i urealnienia tej kategorii w praktyce gospodarowania na gruncie Polski od momentu rozpoczęcia przeobrażeń wtasnościowych, jakie miaty miejsce po 1989 roku. W szczególności uwaga autorki zwrócona jest na jej kluczowy czynnik w postaci innowacyjności wyrażonej poprzez realizacje innowacyjnych postaw $i$ zachowań. W dobie narastajacych niekorzystnych zjawisk wynikajacych $z$ intensyfikacji procesów internacjonalizacji oraz globalizacji niezmiernie istotne jest wzmacnianie potencjału innowacyjnego wspótczesnych przedsiębiorstw w oparciu zarówno o kapitat ludzki, jak $i$ spoteczny. Ponadto, $w$ opracowaniu prezentowane sa podstawowe zatożenia badawcze zawarte w projekcie dotyczacym roli niematerialnych zasobów w ksztattowaniu przewagi konkurencyjnej matych i średnich przedsiębiorstw high-tech z Wielkopolski oraz wstęne ustalenia dotyczqce realizacji przez nie koncepcji przedsiębiorczości intelektualnej.
\end{abstract}

Słowa kluczowe: przedsiębiorczość, innowacyjność, kapitał intelektualny, transformacja systemowa.

Nadesłany: 12.06.2014 | Zaakceptowany do druku: 28.08.2014

\section{Entrepreneurship of SME from high-tech sector of the Great Poland}

The article presents the issues concerning the entrepreneurship category and its implementation in economic practice in Poland since deploying the changes in ownership rights which took place after 1989. In particular, the author's attention is drawn to the key factor in the form of innovation expressed through the implementation of innovative attitudes and behavior. In an era of increasing adverse effects resulting from the intensification of the processes of internationalization and globalization, it is crucial to strengthen the innovative potential of modern enterprise based on both human capital and social as well. In addition, the study presents the basic research assumptions included in the project on the role of intangible resources in the development of a competitive advantage for small and medium-sized high-tech companies from Great Poland and preliminary findings regarding the implementation by them the concept of intellectual entrepreneurship.

Keywords: entrepreneurship, innovation, intellectual capital, system transformation.

Submitted: 12.06.2014 | Accepted: 28.08.2014

JEL: O310

Dr Małgorzata Gajowiak - Politechnika Poznańska, Wydział Inżynierii Zarządzania, Katedra Nauk Ekonomicznych.

Adres do korespondencji: Politechnika Poznańska, ul. Strzelecka 11, 60-965 Poznań, e-mail: malgorzata. gajowiak@put.poznan.pl. 


\section{Wstęp}

W powstałym w 2010 roku, z inicjatywy sektora prywatnego, raporcie pt. „Wizja zrównoważonego rozwoju dla polskiego biznesu 2050" wskazuje się na trzy kluczowe elementy, które istotnie mogą wpłynąć na realizację idei zrównoważonego rozwoju gospodarki polskiej. W opini autorów tego dokumentu czynnikami sukcesu są: system edukacji odpowiadajacy na wyzwania i potrzeby rynku, innowacyjność wyrażająca się gotowością do przekształcania istniejących możliwości w nowe idee i wprowadzania ich do praktycznego zastosowania oraz współpraca zarówno w środowisku biznesu, pomiędzy poszczególnymi sektorami, jak i ta o charakterze regionalnym i międzynarodowym. W szczególności podkreśla się, iż owe elementy należy traktować łącznie, gdyż zachodzą pomiędzy nimi swoiste zależności, np. współdziałanie ośrodków naukowych z biznesem sprzyja innowacyjności. Z kolei „brak efektywnej współpracy i niedopasowanie partnerów oznaczaja mniejsze szanse na zwiększenie efektu synergii w wielu obszarach. Zatrzymanie transferu wiedzy i wymiany doświadczeń między firmami, nastawienie na rywalizację, a nie kooperację, może prowadzić do tego, że firmy nie poznają na czas możliwych rozwiazań, beda powielały błędy, a następnie utracą efektywność i przewagę konkurencyjną" (Price Waterhouse Coopers, 2012, s. 16-21).

Zauważmy tutaj, iż działania przedsiębiorcze wyrażające się postawą proinnowacyjną i nawiązywaniem kooperacji pomiedzy różnymi podmiotami sa szczególnie pożądane w obliczu narastającej luki technologicznej pomiedzy Polska a innymi krajami Europy (Baczko, 2011; Ministerstwo Gospodarki, 2011). Z tego też powodu istotnym wyzwaniem dla przedsiębiorców w naszym kraju jest nadrobienie zaległości rozwojowych przy jednoczesnym poszukiwaniu nowych źródeł przewag konkurencyjnych. Jednym ze sposobów jest odejście od tradycyjnych metod zarządzania koncentrujacych się na efektywności kosztowej danego przedsięwzięcia na rzecz zwiększania innowacyjności opartej na kapitale ludzkim oraz kapitale społecznym. Innowacyjność taka stanowić może klucz do zwiększenia konkurencyjności polskiej gospodarki (Skawińska, 2012). Ponadto, Władysław Szymański wskazuje, iż zmiana sposobów myślenia jest szczególnie konieczna w obliczu burzliwego otoczenia i uogólnionej niepewności charakteryzujących współczesny system gospodarczy na świecie (Szymański, 2011). Przedsiębiorstwa muszą wobec tego zwiększyć swoją elastyczność oraz posiąść umiejętność skutecznego zarządzania zmianami. Konieczne staje się więc wypracowanie zdolności do „twórczej destrukcji” w myśleniu i działaniu w celu dostosowania się do globalizacji i wykorzystania szans, jakie ona stwarza, a także niwelowania zagrożeń z niej wynikających (Szymański, 2011).

Artykuł obejmuje kwestie dotyczące przedsiębiorczości, a także innowacyjności MŚP w Polsce. Ponadto, w opracowaniu prezentowane są podstawowe założenia badawcze zawarte $\mathrm{w}$ projekcie realizowanym w latach 2013-2014 w województwie wielkopolskim na próbie małych i średnich przedsiębiorstw z branży wysokich technologii. Uzyskane w toku badania wyniki stać się moga źródłem istotnych wskazówek dla wszystkich MŚP, które w obliczu zmiennego otoczenia winny opierać swoją działalność innowacyjną na najnowocześniejszych czynnikach wzrostu gospodarczego w postaci kapitału ludzkiego i społecznego.

\section{Przedsiębiorczość i jej egzemplifikacja w warunkach polskich}

Kategoria przedsiębiorczości znajduje się $w$ centrum zainteresowania badaczy reprezentujących różnorodne dyscypliny nauki ${ }^{1}$. Z jednej strony świadczy to o jej znaczącej roli we współczesnym systemie społecznym i gospodarczym. Z drugiej zaś - komplikuje jej precyzyjne zdefiniowanie. W zwiazku z tym najogólniej można przyjąć, iż przedsiębiorczość wyraża się poprzez racjonalne działania obejmujące swym zakresem (Narski, 2000, s. 26):

1) kojarzenie czynników produkcji (np.pracowników, środków trwałych czy finansowych) w niesprzeczne układy funkcjonalne;

2) postępowanie innowacyjne, które przejawia się doskonaleniem techniki, technologii czy sposobów organizacji, co prowadzi do pojawienia się potencjalnych korzyści w postaci m.in. nowych rynków zbytu i zaopatrzenia, nowych surowców, materiałów i kwalifikacji pracowników; 
3) dywersyfikację asortymentu produktów i usług oraz ich cen, a zwłaszcza nowych ulepszonych produktów;

4) przeciwstawianie się konkurencji ze strony innych podmiotów bądź zawieranie z nimi związków strategicznych w celu dalszego rozwoju własnej firmy.

Warto tu również zwrócić uwagę, iż „przedsiębiorczość nie może być [...] zredukowana wyłącznie do porządku techniczno-ekonomicznego, która znajduje swój wyraz jedynie w efektywnym pomnażaniu dóbr. Przedsiębiorczość kojarzona z dobrobytem odnosi się także do sfery wartości i dziedzictwa kulturowego historycznych form zbiorowości ludzkich. Zyskuje przez to ugruntowanie w porządku kulturowym" (Janasz, 2012, s. 25).

Należy podkreślić, iż analizowana tu kategoria ściśle powiązana jest z ustrojem gospodarczym obowiązującym w danym kraju. Jak trafnie zauważają bowiem D. Piątek oraz K. Szarzec, o działaniach przedsiębiorczych nie może być mowy w gospodarce centralnie zarządzanej, która jest silnie zetatyzowana, a obszar wolności gospodarczej zredukowany jest „do drobnych transakcji życia codziennego" (Piątek i Szarzec, 2008, s. 78). Z tego też powodu - jak konstatuje W. Janasz - „przedsiębiorczość jest istotnym wyznacznikiem procesów transformacji ustrojowej zachodzące w krajach Europy Środkowo-Wschodniej” (Janasz, 2012, s. 24).

Zauważmy więc tutaj, iż na gruncie Polski o urealnieniu kategorii przedsiębiorczości w praktyce gospodarczej można niewątpliwie mówić dopiero od momentu rozpoczęcia po 1989 roku transformacji ustrojowej, której najistotniejszym elementem były przeobrażenia w sferze gospodarowania. Zmiany te podyktowane były przy tym całkowitym rozkładem gospodarki, hiperinflacją oraz utratą przez złotego cech pieniądza transakcyjnego (Wilczyński, 2008). Tworzenie nowego systemu gospodarczego, w którym obecny jest duch przedsiebiorczy, obejmowało przy tym w szczególności dwa obszary. Pierwszy, związany był ze zmianami w sposobie regulowania gospodarki, tj. z planistycznonakazowego mechanizmu w mechanizm rynkowy. Z kolei drugi dotyczył zmiany struktury własności gospodarki poprzez tworzenie przedsiębiorstw prywatnych oraz prywatyzację przedsiębiorstw państwowych (Bałtowski, 2008). Działania te opierały się na fundamentalnym założeniu klasycznego liberalizmu, zgodnie z którym wyższe korzyści osiąga społeczeństwo, które funkcjonuje w warunkach wolnego rynku, wykorzystując szeroki wachlarz uprawnień własnościowych (Piątek i Szarzec, 2008). Jak argumentował D. Ricardo (1957, s. 95), „,dopóki każdy może swobodnie, według własnego uznania, wybierać dziedzinę zastosowania swego kapitału, będzie naturalnie starał się o użycie go w sposób najkorzystniejszy".

W rezultacie więc liberalizacji życia gospodarczego w Polsce działalność przedsiębiorstw publicznych malała, a powstające nowe firmy prywatne (głównie mikro i małe) intensywnie podejmowały swoje wysiłki na rynku krajowym, a także stopniowo na rynku międzynarodowym. Eksplozja przedsiębiorczości po 1989 roku doprowadziła więc do sytuacji, iż w 2013 r. Polska zajęła szóste miejsce wśród krajów UE27 pod względem liczby MŚP wynoszącej 1477671 (Komisja Europejska, 2013, s. 2). Podmioty te generuja prawie połowę polskiego $\mathrm{PKB}$ oraz są miejscem pracy dla około $70 \%$ pracujących (PARP, 2012, s. 15-20).

Podsumowując okres 25 lat od wspomnianych tu przeobrażeń, można wysunąć ogólniejszą konstatację, iż polscy przedsiębiorcy wykorzystali szansę, jaką niosła ze sobą zmiana systemu gospodarowania. Dowodem tego są wyniki najnowszego opracowania pt. „Przedsiębiorstwa i przemysł. Arkusz informacyjny SBA 2013", który stanowi cenne źródło porównań pomiędzy krajami unijnymi. Z raportu tego jednoznacznie wynika, iż Polska znacząco wyróżnia się pod względem przedsiębiorczości na tle pozostałych krajów unijnych. Przykładowo, wyższe w naszym kraju niż w krajach UE27 są chociażby: wskaźnik zamiaru rozpoczęcia własnej działalności gospodarczej (dla Polski 22\%, a w UE27 $13 \%$ ), wskaźnik preferowanego samozatrudnienia (PL - 47\%, UE27 - 37\%) czy możliwości założenia własnej działalności gospodarczej (PL - 49\%, UE27 - 30\%). Ponadto, największe postępy polskich przedsiębiorców zauważono w zakresie dostrzegania przez osoby dorosłe możliwości rozpoczęcia pracy na własny rachunek. W 2009 r. przedsiębiorców wyrażających taką opinię było 36\%, a już w 2012 r. prawie $50 \%$. Jak wskazuje się w opracowaniu, jednym $\mathrm{z}$ istotnych czynników odpowiedzialnych za poprawę tej sytuacji jest 
zlikwidowanie wielu barier o charakterze administracyjnym, co znacząco uprościło tworzenie nowych firm (Komisja Europejska, 2013, s. 13).

\section{Innowacyjność MŚP na tle państw unijnych}

Niestety wysokie pokłady przedsiębiorczości w Polsce nie korespondują ze stopniem innowacyjności podmiotów gospodarujących, co bezpośrednio rzutuje również na konkurencyjności firm oraz gospodark jako całości. Dodajmy tutaj, iż na potrzebę „twórczej destrukcji” i podążanie w kierunku rewolucjonizowania produkcji i produktów poprzez wykorzystanie nowych pomysłów w celu osiągania lepszej pozycji na rynku wskazywał już prekursor koncepcji przedsiębiorczości J. Schumpeter, argumentując, iż „nie tyle liczy się konkurencja za pomoca cen i produkcji, ile konkurencja poprzez wprowadzenie nowych towarów i nowych technologii" (1939, s. 45).

I tak, jak wynika $\mathrm{z}$ rankingu Innovation Union Scoreboard 2014, Polska zajmuje 25. miejsce wśród 28 krajów UE (czwarta pozycja od końca, wyższa jedynie od takich państw, jak Rumunia, Łotwa oraz Bułgaria) $\mathrm{z}$ indeksem innowacyjności na poziomie 0,3 przy średniej UE 0,58. Wynik ten pozwala zakwalifikować nasz kraj do grupy państw umiarkowanych innowatorów (moderate innovators). Pocieszający może być fakt, iż Polska jako jedyny kraj unijny w porównaniu $\mathrm{z}$ rokiem 2012 awansowała do wyższej grupy, gdyż wcześniej była członkiem zbioru państw określanych jako najmłodsi innowatorzy (modest innovators). Co jednak nie napawa optymizmem, w aktualnej grupie - jak wynika z przytaczanego tu rankingu - Polska radzi sobie we wszystkich 25 badanych obszarach najgorzej. I tak, w zbiorze tym Polska odnotowała prawie najsłabszy wzrost (zaledwie o 0,88\% wyprzedzając tylko Chorwacje, w której odnotowano progres o $0,77 \%$ ), niższy od średniego dla wszystkich krajów UE, co przyczynia się do powiększania się luki rozwojowej między naszym krajem a UE (European Union, 2014, s. 5 i n.).

Co wieccej, wydatki publiczne na $B \& R$ w Polsce w 2013 r. były na poziomie zaledwie $0,56 \%$ PKB, przy średniej UE28 wynoszącej $0,75 \%$ PKB. Oznacza to, że nadal nasz kraj daleki jest od spełnienia postulatów przyjętych w 2010 r. w Stra- tegii Europa 2020, które zakładają m.in. wzrost nakładów na B\&R do 2020 roku do poziomu minimum $3 \%$ PKB. Z kolei wydatki przedsiębiorstw prywatnych zaliczanych do sektora MŚP na B\&R stanowiły w analizowanym roku jedynie $0,33 \% \mathrm{PKB}$, przy unijnej średniej na poziomie $1,31 \%$ PKB. Jednocześnie tylko 14,4\% oraz 19,9\% MŚP wprowadziło odpowiednio innowacje produktowe i procesowe oraz innowacje marketingowe i organizacyjne przy średniej UE28 na poziomie $38,4 \%$ oraz $40,30 \%$ (European Union, 2014, s. 83). Ponadto, zaledwie 4 na 100000 MŚP uczestniczy w badaniach finansowanych przez UE, przy średniej unijnej na poziomie 23 przedsiebiorstw na 100000 małych i średnich podmiotów gospodarujących (Komisja Europejska, 2013, s. 13). Co więcej, nie napawa optymizmem fakt, iż niższa jest Polsce $(4,2 \%)$ niż w pozostałych krajach Unii (średnia - 11,7\%) świadomość możliwości nawiązania korzystnej dla dwóch stron współpracy wśród MŚP (European Union, 2014, s. 83). Stan ten negatywnie wpływa zarówno na rozwój technologii, jak i transfer wiedzy, a zatem szeroko pojętą innowacyjność (Price Waterhouse Coopers, 2012, s. 30). Małe i średnie podmioty w Polsce nie sa zainteresowane także wzrostem umiejętności swoich pracowników (tylko $10 \%$ z nich przy średniej unijnej na poziomie 19\%) (GEM Polska, 2013, s. 11-12).

\section{Założenia badawcze}

W latach 2013-2014 realizowany był projekt własny pt. „Rola zasobów niematerialnych $\mathrm{w}$ kształtowaniu przewagi konkurencyjnej przez przedsiębiorstwa high-tech w Wielkopolsce"2. Podstawowym problemem badawczym było w nim rozpoznanie stopnia, w jakim małe i średnie przedsiębiorstwa high-tech ${ }^{3}$ wykorzystują miękkie czynniki produkcji w postaci kapitału ludzkiego i społecznego w procesie zdobywania nadrzędnej pozycji nad konkurentami. W badaniu poszukiwano więc odpowiedzi m.in. na następujące pytania:

1) w oparciu o jakie zasoby/umiejętności małe i średnie przedsiębiorstwa wysokich technologii budują źródła przewagi konkurencyjnej, aby zdobyć pozycję na rynku?

2) czy opieraja one swoje działania innowacyjne na świadomym wykorzystywaniu 
twardych czynników i nieprzypisywaniu decydującej roli czynnikom miękkim?

3) czy być może podmioty te waloryzuja czynniki niematerialne (m.in. kapital ludzki, kapitał społeczny)?

4) a jeśli tak, to czy kapitał ludzki i społeczny traktowane są przez menedżerów tych firm za jednakowo istotne zasoby?

5) czy menedżerowie analizowanych przedsiębiorstw upatrują w nich odmienne roli w kształtowaniu przewagi konkurencyjnej?

6) we współpracy $\mathrm{z}$ jakimi podmiotami przedsiębiorstwa te kształtują swój potencjał innowacyjny?

7) jakiej pomocy oczekują ze strony instytucji formalnych mającej na celu rozwój zasobu innowacyjności?

Próba odpowiedzi na te pytania jest istotna, gdyż, jak wskazuje W. Janasz, „przedsiębiorstwa w dominującej mierze przywiązują wagę do bieżącej efektywności, reprezentują tradycyjne podejście, natomiast zbyt mało podmiotów gospodarujących wzbiera strategię, której istotą są zmiany, innowacyjność i elastyczność a więc podejście prospektywne" (2012, s. 37). W związku $\mathrm{z}$ tym istotne jawi sie zidentyfikowanie innowacyjnych podmiotów gospodarczych, a następnie przeanalizowanie warunków oraz czynników charakteryzujących proces kreowania przez nie innowacyjnych pomysłów. Ponadto, warto również rozpoznać potencjalne bariery tego stanu oraz sieci powiązań $z$ podmiotami sceny innowacyjnej. Uzyskane wyniki mogą stać się kluczowe w kształtowaniu potencjału innowacyjnego polskich przedsiębiorstw. Przy czym należy wziąć tu pod uwage nie tylko czynniki stricte ekonomiczne, a więc m.in. zasoby fizyczne i finansowe, lecz także te poza sfery materialnej, które kształtują innowacyjność, a zatem i konkurencyjność danego podmiotu. Jak trafnie wskazuje bowiem T. Gruszecki, determinanty innowacyjnych zachowań odnaleźć także można „,[..] w kulturze, wzorach i wartościach samego społeczeństwa” (1996, s. 8-125). Fakt ten jest szczególnie istotny dla Polski, bowiem „w transformowanej gospodarce ma miejsce uwarunkowany kontekstualnie proces społeczny tworzenia szans na pomnażanie bogactwa, jak również wykorzystania zasobów materialnych i politycznych, a także kapitału społecznego i ludzkiego" (Janasz, 2012, s. 34).
W realizowanym projekcie analizą objęto grupę małych i średnich przedsiębiorstw high-tech z Wielkopolski. Dobór taki podyktowany był przy tym następującymi przesłankami:

1) MSP to najliczniejsza grupa przedsiębiorstw w Polsce (około 99,8\%), stad ich stan i perspektywy dalszego rozwoju w największym stopniu obrazują potencjał przedsiębiorczości i innowacyjności;

2) podmioty te najsilniej odczuwają bariery w prowadzeniu swojej działalności;

3) szczególnie małe przedsiębiorstwa mają wiele do nadrobienia pod względem innowacyjności; jak zauważają autorzy raportu pt. „Analiza zróżnicowania regionalnego aktywności inwestycyjnej sektora MSP, ze szczególnym uwzględnieniem działalności innowacyjnej”, „[...] Przedsiębiorstwa sektora MSP zdecydowanie rzadziej niż podmioty duże inwestują w innowacje, dlatego też efekty działalności innowacyjnej są tutaj tak mało dostrzegalne" (Departament Analiz i Prognoz, 2010, s. 15);

4) szansy na zniwelowanie zapóźnienia technologicznego upatruje się $\mathrm{z}$ rozwojem małych i średnich przedsiębiorstw działających w obszarach zaliczanych do sektora high-tech (Mizgajska i Wścibuk, 2008); wynika to z faktu, iż, ,sektor wysokiej techniki, z uwagi na wysokie natężenie procesów badawczych i rozwojowych jest szczególnym sektorem, którego analiza dostarcza nie tylko informacji o wpływie działalności $\mathrm{B} \& \mathrm{R}$, ale również o konkurencyjności i zdolności gospodarki do absorpcji rezultatów prac z dziedzin nauki i techniki" (Departament Analiz i Prognoz, 2009, s. 3).

Z kolei wybór zakresu terytorialnego nie jest przypadkowy i wynika z faktu, iż województwo wielkopolskie na przestrzeni lat 2008-2012 znacząco wyróżniało się na tle innych województw w kraju pod względem wielkości nakładów na działalność innowacyjną oraz działalność B\&R małych i średnich przedsiebiorstw przemysłowych i usługowych, a także pod względem największej liczby istotnych koncentracji zatrudnionych w przemysłowych branżach high-tech (Departament Analiz i Prognoz, 2010, s. 16 i n.; Wojnicka, 2006, s. 111).

Z urzędu statystycznego pozyskano baze 263 przedsiębiorstw, które należą do grupy małych i średnich podmiotów gospodarujących, reprezentują sektor high-tech, 
a także zlokalizowane są w województwie wielkopolskim. Badanie miało charakter kompletny. Menedżerów firm poproszono o wypełnienie anonimowego kwestionariusza ankiety. Ostatecznie zwrotność ankiet utrzymała się na poziomie $50 \%$. Większość podmiotów z próby badawczej zlokalizowanych była w samym Poznaniu i reprezentują one sekcje: $\mathrm{J}^{4}, \mathrm{C}^{5}$ oraz $\mathrm{M}^{6}$.

Uzyskane wstępne wyniki badania przeprowadzonego wśród MŚP z sektora high-tech wskazują, iż podmioty te realizują nowoczesny paradygmat zarządzania oparty na koncepcji przedsiębiorczości intelektualnej, która „wiąże się z inteligentnym wykorzystaniem posiadanej wiedzy zmierzającym do tworzenia nowej wiedzy i nowych umiejętności, która prowadzi do urzeczywistnienia unikatowych przedsięwzięć. Wszystko to pozwala na oduczenie się rutynowych, tradycyjno-zwyczajowych zachowań" (Janasz, 2012, s. 30). Przedsiębiorstwa te pretendują więc do miana organizacji inteligentnych, gdyż sa w stanie tworzyć podstawy materialnego dobrobytu $\mathrm{z}$ niematerialnej wiedzy. W tym celu koncentrują one swoje wysiłki na budowie przewagi konkurencyjnej w oparciu o wybrane elementy kapitału intelektualnego, tj. kapitału ludzkiego, społecznego oraz organizacyjnego ${ }^{7}$. W szczególności na podstawie analizy trzech podstawowych miar, tj. średniej arytmetycznej, dominanty i mediany, zaobserwowano upatrywanie znaczącej roli w poszczególnych typach kapitałów oraz ich atrybutach. I tak, w przypadku kapitału ludzkiego waloryzacji podlegał zasób w postaci kwalifikacji, umiejętności oraz doświadczenia pracowników, a także ich przedsiębiorczości, w obszarze kapitału społecznego menedżerowie przebadanych przedsiębiorstw świadomi byli roli wartości, takich jak zaufanie, lojalność i wiarygodność zarówno w stosunku do współpracowników, jak i partnerów biznesowych. Z kolei w przypadku kapitału organizacyjnego najistotniejszym czynnikiem w kształtowaniu swojej nadrzędnej pozycji nad konkurentami były: własność intelektualna, innowacyjność przedsiębiorstw, a także organizacyjne uczenie się i gotowość do zmian.

Na podkreślenie zasługuje tutaj fakt, iż przedsiębiorstwa te upatrywały szansy swojego rozwoju nie tylko w działaniach opartych na twardych czynnikach wzrostu, ale przede wszystkim w waloryzacji zasobów miękkich, niematerialnych, a często i trudnych $\mathrm{w}$ precyzyjnym pomiarze. Ponadto, przedsiębiorstwa te (aż $83 \% \mathrm{z}$ nich) świadome były wagi odpowiedniego doboru osób zatrudnionych pod względem umiejętności i kwalifikacji z umiejętnościami społecznymi. Podejście takie zgodne jest $\mathrm{z}$ najnowszymi ustaleniami badaczy organizacji i zarządzania, którzy wskazują, iż „właśnie te drugie będą decydowały o przydatności pracowników dla organizacji i zaangażowaniu w tworzenie nowych wartości, bo kompetencje społeczne decydują o akceptowaniu wartości wspólnych przedsiębiorstwa i jego kultury oraz dzielenia się nimi" (Harasim, 2012, s. 19). Dodajmy tutaj, iż koncepcja przedsiębiorczości intelektualnej podkreśla rolę czynników kulturowych oraz systemu wyznawanych wartości w procesie podejmowania decyzji. Jak podaje K. Czop, „zachowania społeczne, wiedza, umiejętności i doświadczenia wpisują się w społeczną sferę organizacji. To dzięki licznym interakcjom zachodzącym między uczestnikami organizacji, procesom przekazywania informacji i wiedzy oraz procesom uczenia się, organizacja zdolna jest do przetrwania na rynku. Nowoczesna organizacja inspiruje i wspomaga uczenie się wszystkich jej członków, sama ciągle się przekształca, poszerzając swoje możliwości twórcze dla efektywnego kreowania przyszłości” (Czop, 2001, s. 98).

\section{Podsumowanie}

Nie podlega kwestii, iż przeobrażenia transformacyjne, jakie miały miejsce w Polsce po 1989 roku, dały sposobność do tworzenia sektora prywatnego, w którym aktywną rolę odgrywają przedsiębiorcy. Podmioty te angażują się na własne ryzyko w działalność gospodarczą, wykorzystując dostępne im zasoby w celu osiagania korzyści o charakterze ekonomicznym i pozaekonomicznym (np. zmiana statusu społecznego, wizerunku i reputacji). Jak zauważa W. Janasz, ,artykułowanie roli przedsiębiorcy doprowadziło do wykształcenia się współczesnych teorii przedsiębiorstw [...], jak również podejścia badawczego i postulatywnego, które funkcje przedsiębiorcy i przedsiębiorczości uznają za podstawowe we współczesnych gospodarkach rynkowych. Zasób przedsiębiorczości uznaje się za najcenniejszy kapitał współczesnych społeczeństw" (2012, s. 28). 
$\mathrm{Na}$ gruncie Polski potencjał przedsiębiorczości rozumiany $\mathrm{w}$ tradycyjny sposób jako kojarzenie czynników produkcji oraz dywersyfikację towarów i ich cen jest wysoki i szeroko wykorzystywany. Dowodem tego są przytaczane w artykule dane, które jednoznacznie wskazuja, iż po 25 latach od momentu rozpoczęcia zmian w zakresie gospodarowania Polska znacząco wyróżnia się na tle innych państw unijnych pod względem podstawowych mierników tejże przedsiębiorczości. Niestety, poszerzając zakres definicyjny tejże kategorii o ujęcie biorące pod uwage zachowania proinnowacyjne i tym samym utożsamianie przedsiębiorcy $\mathrm{z}$ innowatorem, a więc i z promotorem wzrostu gospodarczego, można stwierdzić, iż potencjał polskich przedsiębiorstw daleki jest od stanu pożądanego. Potwierdzaja to niskie noty Polski w europejskim rankingu innowacyjności. Uprawniona staje się więc tu ogólniejsza konstatacja, iż w naszym kraju przedsiębiorczość MŚP nie realizuje sie poprzez innowacyjność, która powszechnie uznawana jest za warunek konieczny w walce o pozycję na zglobalizowanym rynku.

Ponadto, w artykule przedstawiono założenia badawcze oraz wstepne wyniki badań własnych nad MŚP sektora high-tech z Wielkopolski. Uzyskane dane pozwalają wnioskować, iż przedsiębiorstwa te można zaliczyć do miana innowacyjnych podmiotów, które realizują swoje działania w oparciu o trzy podstawowe składowe kapitału intelektualnego, tj. kapitał ludzki, społeczny i organizacyjny. Oznacza to, iż przedsiębiorstwom tym nieobca jest koncepcja przedsiębiorczości intelektualnej, która stanowić może, pomimo hiperkonkurencji, niepewności i nieufności obecnych na współczesnym rynku, źródło przewagi konkurencyjnej. Ustalenia powyższe moga stać się cenną wskazówką dla tych przedsiębiorstw, które na chwilę obecną nie prezentuja prospektywnego podejścia do realizacji kategorii przedsiębiorczości w praktyce.

\section{Przypisy}

1 Niewątpliwie jej prekursorami byli A. Smith oraz J.B. Say, a swój istotny wkład w rozwój tej kategorii wnieśli także J. Schumpeter oraz P. Druker.

2 Badanie realizowane jest wraz $\mathrm{z}$ mgr inż. A. Libertowską w ramach projektu DS - Młoda
Kadra na Wydziale Inżynierii Zarządzania Politechniki Poznańskiej finansowanego ze środków Ministerstwa Nauk i Szkolnictwa Wyższego.

3 W klasyfikacji dziedzin zaawansowanych technologii przyjęto metodologię określoną przez Eurostat, oparta na sprawozdawczości statystycznej państw członkowskich, kandydujących, stowarzyszonych w Europejskim Stowarzyszeniu Wolnego Handlu (EFTA) oraz stron trzecich. Według tej klasyfikacji, do branż zaawansowanych technologii zgodnie z Polską Klasyfikacja Działalności (PKD 2007) zaliczane są następujace działy (GUS, 2012, s. 180-181, na podstawie danych Eurostatu): C 21, C 26, C 30.3, J 59, J 60, J 61, J 62, J 63, M 72.

4 Firmy $\mathrm{z}$ tej sekcji reprezentują następujące działy: działalność związana z produkcja filmów, nagrań wideo i programów telewizyjnych; działalność związana z projekcją filmów; nadawanie programów telewizyjnych ogólnodostepnych i abonamentowych; działalność w zakresie telekomunikacji przewodowej; działalność w zakresie telekomunikacji bezprzewodowej, z wyłączeniem telekomunikacji satelitarnej; działalność związana z oprogramowaniem; działalność związana z doradztwem w zakresie informatyki; działalność związana z zarządzaniem urządzeniami informatycznymi; pozostała działalność usługowa w zakresie technologii informatycznych i komputerowych; przetwarzanie danych: zarządzanie stronami internetowymi (hosting) i podobna działalność; przetwarzanie danych: zarządzanie stronami internetowymi (hosting) i podobna działalność; działalność portali internetowych.

5 Firmy z tej sekcji reprezentują z kolei działy: produkcja leków i pozostałych wyrobów farmaceutycznych; produkcja elementów elektronicznych; produkcja elektronicznych obwodów drukowanych; produkcja komputerów i urządzeń peryferyjnych; produkcja sprzętu (tele)komunikacyjnego; produkcja elektronicznego sprzętu powszechnego użytku; produkcja instrumentów i przyrządów pomiarowych, kontrolnych i nawigacyjnych; produkcja instrumentów optycznych i sprzętu fotograficznego; produkcja statków powietrznych, statków kosmicznych i podobnych maszyn.

6 Firmy z tej sekcji reprezentują działy: badania naukowe i prace rozwojowe w dziedzinie pozostałych nauk przyrodniczych i technicznych; badania naukowe i prace rozwojowe w dziedzinie nauk społecznych i humanistycznych.

7 W badaniu przyjęto konceptualizację kapitału intelektualnego za: Bratnicki i Strużyna, 2001. W opinii autorów kapitał intelektualny to agregat trzech składowych: kapitału społecznego (powiązania w sieci, konfiguracja sieci, odpowiedzialność organizacji, zaufanie, normy, zobowiązania, identyfikacja, wspólnie podzielane 
słowniki, wspólny język, wspólnie podzielane obowiązki), kapitału ludzkiego (umiejętności praktyczne (biegłość), wiedza teoretyczna, talenty, innowacyjność ludzi, zdolność do naśladowania, przedsiębiorczość, zdolność do zmian, chęć działania, predyspozycje zawodowe, zaangażowanie $\mathrm{w}$ procesy organizacyjne, władza organizacyjna, przywództwo menedżerskie) oraz organizacyjnego (struktura organizacyjna, systemy działania, własność intelektualna, procesy wewnętrzne, kultura organizacyjna, zasoby rynkowe, powiązania $\mathrm{z}$ dostawcami, powiązania z udziałowcami, powiązania z partnerami aliansów strategicznych, powiązania $\mathrm{z}$ innymi zainteresowanymi, innowacyjność przedsiębiorstw, organizacyjne uczenie się, zamierzenie strategiczne, cele i strategie przedsiębiorstwa, procesy tworzenia strategii, gotowość do zmian).

\section{Bibliografia}

Baczko, T. (red.) (2011). Raport o innowacyjności gospodarki Polski w 2010 roku. Warszawa: Instytut Nauk Ekonomicznych PAN.

Bałtowski, M. (2008). Liberalne aspekty transfor macji gospodarczej w Polsce. W: W. Jarmołowicz, M. Ratajczak (red.), Liberalizm we wspótczesnej gospodarce. Poznań: Wydawnictwo Akademii Ekonomicznej w Poznaniu.

Bratnicki, M. i Strużyna J. (2001). Przedsiębiorczość $i$ kapitat intelektualny. Katowice: Wydawnictwo Akademii Ekonomicznej im. K. Adamieckiego w Katowicach.

Czop, K. (2001). Wiedza, zmiana i uczenie się jako determinanty kultury nowoczesnej organizacji. Zarzadzanie Wiedza, 1. Kraków-Zabrze: Oficyna Wydawnicza Stowarzyszenie na Rzecz Rozwoju Nauki Polskiej.

Departament Analiz i Prognoz. (2009). Konkurencyjność sektora wysokiej techniki. Warszawa: Ministerstwo Gospodarki.

Departament Analiz i Prognoz. (2010). Analiza zróżnicowania regionalnego aktywności inwestycyjnej sektora MŚP, ze szczególnym uwzględnieniem działalności innowacyjnej. Warszawa: Ministerstwo Gospodarki.

European Union. (2014). Innovation Union Scoreboard. Brussel.

GEM Polska. (2013). Warszawa: Polska Agencja Rozwoju Przedsiębiorczości.

Gruszecki, T. (1996). Przedsiębiorca w teorii ekonomii. Warszawa: Cedar.

GUS. (2012). Nauka i Technika w 2011 r. Warszawa: GUS.

Harasim, W. (2012), Wykorzystanie kapitału intelektualnego w zarządzaniu organizacją inte- ligentną dla tworzenia przewagi konkurencyjnej. W: W. Harasim (red.), Zarzadzanie kapitatem intelektualnym $w$ organizacji inteligentnej. Warszawa: Wyższa Szkoła Promocji.

Janasz, W. (2012). Przedsiębiorczość i przedsię biorcy jako kategorie współczesnych organizacji W: J. Wiśniewska i K. Janasz (red.), Innowacyjnośc organizacji $w$ strategii inteligentnego i zrównoważonego rozwoju. Warszawa: Wydawnictwo Difin.

Komisja Europejska. (2013). Przedsiębiorstwa i przemysł. Arkusz informacyjny SBA 2013 Pobrano z: http://ec.europa.eu/enterprise/policies/ sme/facts-figures-analysis/performance-review/files/ countries-sheets/2012/poland_pl.pdf (23.01.2014).

Ministerstwo Gospodarki. (2011). Strategia innowacyjności i efektywności gospodarki na lata 2011-2020. Dynamiczna Polska. Warszawa: MG.

Mizgajska, H., Wściubiak, Ł. (2002). Wpływ wybranych czynników na aktywność innowacyjną MŚP sektora high-tech. W: E. Okoń-Horodyńska i A. Zachorowska-Mazurkiewicz A. (red.), Tendencje innowacyjnego rozwoju polskich przedsiębiorstw. Warszawa: Instytut Wiedzy i Innowacji.

Narski, Z. (2000). Ekonomia. Nauka o gospodarowaniu. Toruń: Suspens.

PARP. (2012). Raport o stanie sektora małych i średnich przedsiębiorstw w Polsce w latach 2010-2011. Warszawa.

Piątek, D. i Szarzec, K. (2008). Liberalna koncepcja jednostki gospodarującej i jej implikacje dla transformacji gospodarczej. W: W. Jarmołowicz i M. Ratajczak (red.), Liberalizm we wspótczesnej gospodarce. Poznań: Wydawnictwo Akademii Ekonomicznej w Poznaniu.

Price Waterhouse Coopers. (2012). Wizja zrównoważonego rozwoju dla polskiego biznesu 2050 Warszawa.

Ricardo, D. (1957). Zasady ekonomiki politycznej i opodatkowania. Warszawa: PWN.

Schumpeter, J.A. (1939). Busniess Cycle. New York \& London: McGrow-Hill Book Co. Inc.

Skawińska, E. (2012). Wpływ kapitału społecznego na przedsiębiorczość i innowacyjność podmiotów. W: E. Skawińska (red.), Kapitat spoteczny w rozwoju regionu. Warszawa: PWN

Szymański, W. (2011). Niepewność i niestabilność gospodarcza. Warszawa: Wydawnictwo Difin.

Wilczyński, W. (2008). Spory o polską transformacje - dylematy, nieporozumienia, błędy. W: W. Jarmołowicz i M. Ratajczak (red.), Liberalizm we wspótczesnej gospodarce. Poznań: Wydawnictwo Akademii Ekonomicznej w Poznaniu.

Wojnicka, E. (red.). (2006). Perspektywy rozwoju malych i średnich przedsiębiorstw wysokich technologii w Polsce do 2020 roku, Warszawa: PARP. 